\title{
The occupational risk of Helicobacter pylori infection: a systematic review
}

\author{
Hassan Kheyre ${ }^{1} \cdot$ Samantha Morais $^{1} \cdot$ Ana Ferro $^{1} \cdot$ Ana Rute Costa $^{1} \cdot$ Pedro Norton $^{1,2} \cdot$ Nuno Lunet $^{1,3}$. \\ Bárbara Peleteiro ${ }^{1,3}$ (1)
}

Received: 8 January 2018 / Accepted: 22 May 2018 / Published online: 29 May 2018

(c) Springer-Verlag GmbH Germany, part of Springer Nature 2018

\begin{abstract}
Purpose The aim of this systematic review was to describe the prevalence of Helicobacter pylori infection in specific occupational groups and to compare them with the general population.

Methods We searched PubMed® to identify original studies reporting the prevalence of $H$. pylori infection in occupational groups. The differences between occupational groups and the general population were analyzed taking into account the direction and statistical significance of the differences observed when comparing each occupational group with a reference group (either recruited in the same study or using an external comparator).

Results A total of 98 studies addressing the prevalence of $H$. pylori infection in occupational groups were included in the systematic review. Overall, health professionals showed a significantly higher prevalence of $H$. pylori infection than the general population, especially among those working at gastrointestinal units. Similar results were found in subjects involved in agricultural, forestry and fishery, as well as in sewage workers, miners, and workers at institutions for the intellectually disabled, although differences were less pronounced.

Conclusions Our results show an occupational risk of H. pylori infection supporting the role of oral-oral, fecal-oral, and zoonotic transmission. Studies comparing specific occupational groups with adequate comparators may contribute to better identify groups at higher risk of infection. The recognition of this infection as an occupational disease would result in early detection and treatment, as well as prevention and control of its transmission in workplaces.
\end{abstract}

Keywords Helicobacter pylori $\cdot$ Prevalence $\cdot$ Occupations $\cdot$ Systematic review

Electronic supplementary material The online version of this article (https://doi.org/10.1007/s00420-018-1315-6) contains supplementary material, which is available to authorized users.

Bárbara Peleteiro

barbarap@med.up.pt

1 EPIUnit, Instituto de Saúde Pública, Universidade do Porto, Rua das Taipas 135, 4050-600 Porto, Portugal

2 Unidade de Saúde Ocupacional, Centro de Epidemiologia Hospitalar, Centro Hospitalar de São João, Alameda Prof. Hernâni Monteiro, 4200-319 Porto, Portugal

3 Departamento de Ciências da Saúde Pública e Forenses e Educação Médica, Faculdade de Medicina, Universidade do Porto, Alameda Prof. Hernâni Monteiro, 4200-319 Porto, Portugal

\section{Introduction}

\section{Helicobacter pylori}

Helicobacter pylori is a spiral, flagellated, Gram-negative bacterium (Marshall 2002) that is primarily found in the gastric mucosa of humans (Testerman and Morris 2014). Since its discovery in 1983 (Marshall and Warren 1984), it has been recognized as a major causal factor of histological changes leading to severe gastro-duodenal disease including gastric cancer (IARC Working Group on the Evaluation of Carcinogenic Risks to Humans 1994; Peleteiro et al. 2012). Globally, H. pylori infection was estimated to affect more than half of the adult population (Parkin 2006) and to have accounted for almost $80 \%$ of all gastric cancer cases in 2012 (89.0\% in noncardia and $17.8 \%$ in cardia cancers) (Plummer et al. 2016). 
In the last few decades, the prevalence of $H$. pylori infection has been declining (Peleteiro et al. 2014), but there are significant differences in its prevalence both within and between countries (Lunet and Barros 2003). Improvements in socioeconomic and educational levels, namely, regarding sanitation and general living conditions, have been associated with this decrease, which also had an effect on gastric cancer trends, though with significant differences across geographical regions (Ferro et al. 2014).

\section{Diagnosis of $H$. pylori infection}

A number of methods are available for detection of $H$. pylori, which can be classified as invasive or non-invasive. Invasive methods use endoscopy to obtain gastric biopsy specimens for histopathology, microbiological culture or rapid urease tests that detect active infection (Megraud and Lehours 2007). The "gold standard" to detect active $H$. pylori infection still includes the need of a culture obtained from endoscopy, usually complemented with a biopsy urease test and/or histology (Brown 2000). Infection with H. pylori may also be identified by DNA amplification through polymerase chain reaction (PCR); however, this technique is not widely used as it is expensive when compared with culture, histology and rapid urease tests, and requires special laboratory conditions (Megraud and Lehours 2007).

H. pylori infection may also be assessed through noninvasive methods such as antibody-based tests, stool antigen test (SAT), and urea breath test (UBT). A variety of commercial and in-house diagnostic tests have been developed for the detection of $\mathrm{H}$. pylori-specific antibodies in serum, saliva, and urine (Garza-Gonzalez et al. 2014). These tests are also called passive detection methods (Ricci et al. 2007) as they do not measure actual infection but the exposure to the bacteria at some time. Most of these diagnostic tests are serum-based; they are generally simple, reproducible and inexpensive, and can be done using stored samples; thus, they have been used widely in epidemiological studies (Brown 2000). Infection with $H$. pylori may also be diagnosed using SAT. The latter can detect either the bacterium or part of it (DNA or other molecules), and therefore, the infection may be assessed by culture, PCR or by the detection of antigens (Megraud and Lehours 2007), which may be particularly useful for epidemiological studies involving children (Versalovic 2003). Finally, UBT detects current infection and can be used as a screening test for $H$. pylori and to assess if an eradication treatment was successful (Brown 2000); however, the test might be unreliable when assessing patients who have undergone gastric surgery or using urease inhibiting drugs, due to great variations in $\mathrm{pH}$ that may lead to false negative results (Gisbert and Pajares 2004).

\section{H. pylori transmission}

Various pathways for the transmission of H. pylori infection have been described. Person-to-person transmission, including oral-oral, fecal-oral, and gastro-oral routes, appears to be the main mode (Allaker et al. 2002; Leung et al. 1999; Parsonnet et al. 1999). Evidence of the importance of close contacts for the acquisition of the infection comes from studies showing an increased prevalence of infection within institutionalized populations (Bohmer et al. 1997; Lambert et al. 1995) and clustering of H. pylori infection in families (Brenner et al. 2006; Cervantes et al. 2010; Rothenbacher and Brenner 2003), particularly between mothers and their children (Weyermann et al. 2006), and among siblings (Kivi and Tindberg 2006). The detection of $H$. pylori in body fluids, such as feces (Makristathis et al. 1998), gastric juice, urine, and saliva (Vaira and Vakil 2001), has also supported person-to-person transmission of infection (Brown 2000). Therefore, occupationally acquired infections may occur through close personal contact with infected patients or their body fluids (De Schryver et al. 2004). In fact, iatrogenic contamination following endoscopy is still the only proven mode of transmission (Brown 2000). H. pylori can be transmitted through upper gastrointestinal endoscopy (Langenberg et al. 1990; Shimada et al. 1996), nasogastric tubes (Graham et al. 1988), pH probes, and contaminated endoscopes (Roosendaal et al. 1993). The complex structure of medical apparatuses and difficulty in disinfecting them makes iatrogenic infection a potential risk factor for H. pylori infection in health-care workers (Axon 1991; Fantry et al. 1995). In addition, the impact of control measures would affect a large number of individuals, as the health-care sector represents $10 \%$ of all workers in the European Union (European Agency for Safety and Health at Work 2007).

Some studies have also suggested that infection may be acquired from the environment through water (Aziz et al. 2015), possibly due to fecal contamination, especially in areas of the world with deficiencies in water treatment (Brown 2000), or zoonotic transmission (Cover 1997; Megraud and Broutet 2000), through sheep (Dore et al. 1999; Goodman et al. 1996) or houseflies (Osato et al. 1998; Vaira and Holton 1998). Accordingly, contact with contaminated water or infected animals may pose an additional risk of infection in some occupational groups.

\section{Aim}

Identifying the main routes of transmission of $H$. pylori infection should be a priority in health research, as it may 
allow the definition of preventive strategies for further reducing its morbidity and mortality burden. Since different occupations may represent distinct pathways for acquiring the infection, we aimed to describe the prevalence of $H$. pylori infection in specific occupational groups and to compare them with the general population, through a systematic review of published studies.

\section{Methods}

A study protocol was predefined by the authors and followed throughout the review.

\section{Search strategy and selection of studies}

PubMed® was searched, from inception to September 2015, using the search expression provided in the systematic review flowchart shown in Online Appendix A.

Each reference retrieved was screened independently by two reviewers (AF, ARC, and SM were involved in this step), following predefined criteria to determine eligibility for the systematic review. Original studies reporting the prevalence of $H$. pylori in occupational groups were eligible. The exclusion criteria were the following: (1) papers not written in English, Portuguese, Spanish, French, Italian, or Polish; (2) research not involving humans (e.g., in vitro or animal research); (3) non-eligible publication types (reviews, editorials, comments, guidelines, and case reports); (4) studies not evaluating or not providing the prevalence of $H$. pylori infection in specific occupational groups; (5) studies including only $H$. pylori-infected subjects (e.g., $H$. pylori eradication trials); (6) studies with data not related to $H$. pylori prevalence or addressing other outcomes (e.g., cost-effectiveness analyses); and (7) studies with a non-systematic assessment of $H$. pylori infection in biological samples (e.g., self-reported information, secondary data on infection status retrieved from laboratory databases).

When more than one report referred to the same study/ sample, the one presenting the results with more detail (e.g., regarding the prevalence according to specific occupational groups), or providing data for the largest sample was considered, although any of the reports could be used to obtain information on the study characteristics.

The decisions taken independently by the reviewers were compared and discrepancies were resolved by consensus, or after discussion with another researcher (BP).

\section{Data extraction}

Two investigators (HK and BP) evaluated independently the selected studies to extract data regarding: year of publication; period of data collection [when this was not specified, we assumed the publication year minus the median difference between the publication year and the mid-point of years of data collection in the studies for which that information was available (3.5 years)]; sampling procedures; sample characteristics; and methods used to determine H. pylori infection status.

Occupational groups recruited in each study were identified and classified according to the International Standard Classification of Occupations (International Labour Organization 2007).

The prevalence of $H$. pylori in different occupational groups was extracted, and the comparison between the occupational group and a reference group selected by criteria not related with occupation (e.g., general population, blood donors, volunteers), was retrieved whenever available. When studies did not provide data for a suitable reference group, estimates of $H$. pylori prevalence in the general population from the same country were obtained from studies included in a previous systematic review on the prevalence of $H$. pylori worldwide (Peleteiro et al. 2014), among those using the same type of assessment of infection status (past versus active infection) (Miftahussurur and Yamaoka 2016), conducted within 10 years of the corresponding study of occupational groups. If more than one eligible study presenting estimates of infection in age strata similar to the occupational group was available, the following criteria were applied consecutively until only one study was selected: (1) nationally representative or general population samples; (2) data collection closest to the one of the corresponding study of occupational groups; and (3) largest sample size.

Differences in the data extracted by the two investigators were discussed until consensus, and involving a third researcher $(\mathrm{SM})$, whenever necessary.

\section{Data analysis}

Due to the heterogeneity of the occupational groups evaluated in the studies identified through systematic review and options for presenting results in each report, it was not possible to perform a quantitative synthesis of the main findings. Therefore, the differences in the prevalence of $H$. pylori between occupational groups and the general population were analyzed taking into account the direction and statistical significance of the differences observed when comparing each occupational group with a reference group (either from the same study or using an external comparator). Differences were classified as "Lower prevalence" or "Higher prevalence" in the occupational group than in the comparison group. In addition, these differences between the occupational and reference groups were classified as "statistically significant", "not statistically significant" and "not available", as reported in the papers. 
Results were summarized in tables showing the prevalence of infection in occupational groups and the general population or comparison groups, and in harvest plots presenting the number of studies according to the statistical significance.

\section{Results}

\section{Study characteristics}

We identified 98 studies addressing the prevalence of $H$. pylori infection in 144 occupational groups (Online Appendix A and Online Appendix B). The reports were published between 1989 and 2015, and data collection took place between 1969 and 2013. Regarding the geographic coverage, 18 studies were conducted in the Americas, 33 in Asia, 43 in Europe and 4 in Oceania. The studies covered a wide age range, between 17 and 64 years, with sample sizes varying from 19 to 30,810 subjects. Most had a cross-sectional design $(n=75)$, with the exception of eight case-control studies (data extracted referred to the control group) and 15 cohort studies (data extracted referred to the baseline evaluation). The assessment of $H$. pylori status was mainly done using serum samples $(\mathrm{n}=80)$, mostly measuring $\mathrm{IgG}$ antibodies, UBT was used in 14 studies, invasive techniques were used in two, whereas one study each evaluated urine and stool samples.

Tables 1, 2, 3, and 4 present the prevalence of $H$. pylori infection in the occupational groups and in the reference groups. The most frequently studied were health professionals, in a total of 49 studies, followed by studies on armed forces (14 studies). Agricultural, forestry, and fishery workers were evaluated in 8 studies, whereas 9 recruited factory workers and 14 assessed administrative staff. There were four studies each evaluating sewage workers and miners, and travelers. Finally, three studies each recruited teaching professionals, transportation workers, and workers at institutions for intellectually disabled people.

A total of 20 studies compared different occupational groups and in 29 studies the prevalence of infection in specific occupational groups was compared with control groups, selected in the same studies, not defined by occupation (Tables 1, 3). An additional 49 studies did not assess control groups selected based on criteria not including occupation, and therefore, an external comparator was selected for the present analysis (Tables 2, 4).

\section{Health professionals}

$H$. pylori prevalence in health professionals ranged from $3.8 \%$ in anesthesiologists to $82.4 \%$ in gastrointestinal endoscopists. Within gastroenterology staff, gastroenterology nurses presented the lowest values (16.8\%), whereas clinical students were the ones presenting the lowest prevalence $(6.4 \%)$ and dentists the highest $(70.0 \%)$ among dental staff. Figure 1 presents the differences in the prevalence of $H$. pylori infection between health professionals and the reference group. Overall, a total of 13 studies showed a statistically significant higher prevalence of $H$. pylori among health professionals when compared with a reference group, particularly among gastroenterology staff $(n=7)$. However, eight studies recruiting health professionals from gastroenterology departments showed no statistically significant differences or no comparison, despite presenting a higher prevalence of $H$. pylori infection than the comparison groups. Nevertheless, there was a considerable amount of studies showing a lower prevalence of $H$. pylori infection when compared with the reference group, although this difference was only statistically significant in four studies. In addition, a high number of studies did not provide an adequate comparison between the occupational and the reference group $(n=31)$, especially among other health professionals $(n=22)$. For dental staff, most studies showed a lower prevalence of infection among these health professionals than controls $(n=10)$; however, this result was not statistically significant $(n=5)$ or not adequately compared $(n=5)$.

\section{Other occupational groups}

In other occupations, most studies show a lower prevalence of $H$. pylori infection in the occupational groups, but most of them did not present a suitable reference group (Fig. 2).

For administrative staff, $H$. pylori prevalence ranged from $6.1 \%$ in abattoir clerks and painters to $72.0 \%$ in faculty staff. Most studies showed a lower prevalence of $H$. pylori infection when compared to an external comparator. Among agricultural, forestry and fishery workers, H. pylori prevalence was the lowest in pig carcass workers (14.8\%) and the highest in farmers (77.6\%). Three studies showed a higher and seven studies showed a lower prevalence of H. pylori infection for agricultural, forestry, and fishery occupations compared with the reference group, with only one study describing a statistically significant difference. In the armed forces, $H$. pylori prevalence was lower among navy submarine crews (10.4\%) and higher in low-rank officials $(82.5 \%)$. Almost all studies evaluating subjects from the armed forces showed a lower prevalence of $H$. pylori infection when compared with the general population. Even though one study used an in study comparator, no formal comparison was reported. Within the group of factory workers, daytime workers who had never done shift work were the ones presenting the lowest values of $H$. pylori prevalence (13.4\%), while skilled and unskilled professional workers presented the highest value $(69.7 \%)$. Among factory workers, a slightly higher number of studies showed a lower 
Table 1 Prevalence of $H$. pylori infection in health professionals and in study comparators, and $p$ value and/or risk of infection

\begin{tabular}{|c|c|c|c|}
\hline \multirow{2}{*}{$\begin{array}{l}\text { Authors } \\
\text { Year of publication }\end{array}$} & \multicolumn{2}{|l|}{ Prevalence of $H$. pylori infection (\%) } & \multirow{2}{*}{$\begin{array}{l}p \text { Value and/or risk } \\
\text { of infection (RR/OR, } \\
95 \% \mathrm{CI})^{\text {a }}\end{array}$} \\
\hline & Occupational group & In study comparator & \\
\hline (Mitchell et al. 1989) & $\begin{array}{l}\text { Gastroenterologists }=51.5 \\
\text { Gastroenterology nurses }=19.1 \\
\text { General practitioners }=28.6\end{array}$ & Blood donors $=21.5$ & $\begin{array}{l}p<0.01 \\
p=\mathrm{NS} \\
p=\mathrm{NS}\end{array}$ \\
\hline (Reiff et al. 1989) & $\begin{array}{l}\text { Endoscopy staff }=55.5 \\
\text { Dental staff }=27.6\end{array}$ & Controls $=49.3$ & $\begin{array}{l}p=\mathrm{NS} \\
p=\mathrm{NS}\end{array}$ \\
\hline (Royo et al. 1991) & $\begin{array}{l}\text { Gastroenterology medical and nursing } \\
\text { staff }=30.4\end{array}$ & Control group $1=38.5$ & $p=0.620$ \\
\hline (Wilhoite et al. 1993) & $\begin{array}{l}\text { Nurses }=39.2 \\
\text { Resident physicians }=23.7 \\
\text { Nursing students }=13.6 \\
\text { Medical students }=19.6\end{array}$ & Blood donors $=25.8$ & $\begin{array}{l}p<0.01 \\
p=\mathrm{NS} \\
p=\mathrm{NS} \\
\mathrm{p}=\mathrm{NS}\end{array}$ \\
\hline (Chong et al. 1994) & $\begin{array}{l}\text { Gastroenterologists/endoscopy nurses }=53.3 \\
\text { Gastroendoscopists }=52.2 \\
\text { Endoscopy nurses }=54.5\end{array}$ & Healthy blood donors $=14.1$ & $p<0.0001$ \\
\hline (Lin et al. 1994) & $\begin{array}{l}\text { Gastroenterologists }=69.2 \\
\text { General internists }=40.0 \\
\text { Gastroenterology nurses }=16.8 \\
\text { General nurses }=19.0\end{array}$ & $\begin{array}{l}\text { Controls }=36.9 \\
\text { Controls }=37.5 \\
\text { Controls }=27.8 \\
\text { Controls }=24.2\end{array}$ & $\begin{array}{l}\mathrm{OR}=5.00(2.00-12.00) \\
\mathrm{OR}=1.00(0.30-3.10) \\
\mathrm{OR}=0.58(0.28-1.22) \\
\mathrm{OR}=0.90(0.33-2.47)\end{array}$ \\
\hline (Pristautz et al. 1994) & Endoscopists $=47.7$ & Controls $=47.0$ & $p=\mathrm{NS}$ \\
\hline (Banatvala et al. 1995) & $\begin{array}{l}\text { Dental practitioners }=15.7 \\
\text { Clinical dental students }=6.4 \\
\text { Pre-clinical dental students }=9.7\end{array}$ & $\begin{array}{l}\text { Controls }=25.7 \\
\text { Controls }=6.4 \\
\text { Controls }=9.7\end{array}$ & $\begin{array}{l}\mathrm{OR}=0.6(0.2-1.5) \\
\mathrm{OR}=1.0(0.3-3.7) \\
\mathrm{OR}=1.0(0.2-5.4)\end{array}$ \\
\hline (De Vecchi et al. 1995) & Nursing staff $=26.3$ & Blood donors $=58.0$ & $p=\mathrm{NS}$ \\
\hline (Bergenzaun et al. 1996) & Medical students $=10.0$ & Health-care population $=11.8$ & - \\
\hline (Liu et al. 1996) & $\begin{array}{l}\text { Medical staff }=70.0 \\
\text { GI endoscopists }=82.4 \\
\text { Endoscopy nurses }=77.7 \\
\text { GI doctors }=74.6 \\
\text { GI nurses }=74.2 \\
\text { Internists }=66.4 \\
\text { General nurses }=65.8\end{array}$ & Control group $=44.6$ & $\mathrm{OR}=2.90(2.38-3.45)$ \\
\hline (Su et al. 1996) & Endoscopists $=80.0$ & Controls $=51.6$ & $p=0.007$ \\
\hline (Braden et al. 1997) & $\begin{array}{l}\text { Medical staff }=37.1 \\
\text { Endoscopy staff }=37.8 \\
\text { Non-endoscopy medical staff }=35.9 \\
\text { Physicians }=37.4 \\
\text { Endoscopy physicians }=38.0 \\
\text { Non-endoscopy physicians }=36.4 \\
\text { Nurses }=35.3 \\
\text { Endoscopy nurses }=36.7 \\
\text { Non-endoscopy nurses }=31.8\end{array}$ & Controls $=27.1$ & $\begin{array}{l}\mathrm{OR}=1.59(1.25-2.01) \\
\mathrm{OR}=1.63(1.27-2.09) \\
\mathrm{OR}=1.51(1.14-1.98) \\
\mathrm{OR}=1.61(1.26-2.04) \\
\mathrm{OR}=1.64(1.28-2.12) \\
\mathrm{OR}=1.54(1.17-2.04) \\
- \\
\mathrm{OR}=1.80(1.24-2.63) \\
\mathrm{OR}=1.64(0.96-1.64)\end{array}$ \\
\hline (Abbas et al. 1998) & $\begin{array}{l}\text { Endoscopy personnel }=78.8 \\
\text { Endoscopy doctors }=68.4 \\
\text { Endoscopy nurses and assistants }=92.9\end{array}$ & Non-medical subjects $=57.6$ & $\begin{array}{l}p=0.06 \\
p=0.43 \\
p=0.019\end{array}$ \\
\hline (Lin et al. 1998) & $\begin{array}{l}\text { Dentists }=22.8 \\
\text { Dental nurses }=17.5 \\
\text { 5th year dental students }=18.2 \\
\text { 1st year dental students }=16.7\end{array}$ & $\begin{array}{l}\text { Controls }=33.2 \\
\text { Controls }=30.6 \\
\text { Controls }=21.4\end{array}$ & $\begin{array}{l}\mathrm{OR}=0.58(0.30-1.10) \\
\mathrm{OR}=1.00(0.40-2.90) \\
\mathrm{OR}=1.22(0.25-5.90) \\
\mathrm{OR}=1.36(0.27-6.80)\end{array}$ \\
\hline (Nishikawa et al. 1998) & $\begin{array}{l}\text { Endoscopy personnel }=29.8 \\
\text { Gastrointestinal endoscopists }=30.4 \\
\text { Endoscopy nurses }=27.6\end{array}$ & Controls $=24.8$ & $p=0.406$ \\
\hline (Shelley and Haddadin 1998) & Anesthesiologists $=3.8$ & $\begin{array}{l}\text { Control groups }=19.7 \\
\text { (Chong et al. 1994; Wilhoite et al. 1993) }\end{array}$ & $p<0.01$ \\
\hline
\end{tabular}


Table 1 (continued)

\begin{tabular}{|c|c|c|c|}
\hline \multirow{2}{*}{$\begin{array}{l}\text { Authors } \\
\text { Year of publication }\end{array}$} & \multicolumn{2}{|l|}{ Prevalence of $H$. pylori infection (\%) } & \multirow{2}{*}{$\begin{array}{l}p \text { Value and/or risk } \\
\text { of infection (RR/OR, }_{95 \% \mathrm{CI})^{\mathrm{a}}}\end{array}$} \\
\hline & Occupational group & In study comparator & \\
\hline (Mones et al. 1999) & $\begin{array}{l}\text { Medical staff }=52.7 \\
\text { Gastroenterologists }=53.3 \\
\text { Endoscopists }=53.3 \\
\text { Non-endoscopists }=53.5 \\
\text { Non-gastroenterologists }=50.0\end{array}$ & Healthy controls $=51.9$ & $p>0.05$ \\
\hline (Robertson et al. 1999) & ICU nurses $=40.0$ & Blood donors $=19.0$ & $p<0.001$ \\
\hline (Hildebrand et al. 2000) & Gastroenterologists $=39.1$ & Healthy controls $=38.1$ & - \\
\hline (Martinez et al. 2000) & Emergency physicians $=6.8$ & Controls $=15.9$ & - \\
\hline (Pronai et al. 2000) & $\begin{array}{l}\text { Gastroenterologists }=35.2 \\
\text { With endoscopy practice }=29.6 \\
\text { Without endoscopy practice }=38.8 \\
\text { General practitioners }=36.3\end{array}$ & Healthy controls $=54.4$ & $\begin{array}{l}p<0.05 \\
p<0.05 \\
p<0.05\end{array}$ \\
\hline (Honda et al. 2001) & Dentists $=70.0$ & Control group $=38.3$ & $\mathrm{OR}=3.80(1.76-8.02)$ \\
\hline (Upile et al. 2002) & Surgical personnel $=50.0$ & $\begin{array}{l}\text { Control group }=25.7 \\
\text { (Banatvala et al. 1995) }\end{array}$ & $p<0.0001$ \\
\hline (Kim et al. 2013) & $\begin{array}{l}\text { Nurses }=29.8 \\
\text { Doctors }=34.5\end{array}$ & Nonhospital controls $=52.9$ & - \\
\hline
\end{tabular}

$R R$ relative risk, $O R$ odds ratio, 95\% CI 95\% confidence interval, $N S$ not significant, GI gastrointestinal, ICU intensive care unit

aReference category is "in study comparator" and "occupational group" is the risk group, unless otherwise specified

prevalence of $H$. pylori infection when compared to an external control. Sewage workers presented a lower prevalence of H. pylori infection (16.7\%) than miners (48.1\%). In teaching professionals, transportation workers and travelers, $H$. pylori prevalence ranged from 24.1 to $45.1 \%$ in the first group, from 37.0 to $77.4 \%$ in the second, and from 17.0 to $91.7 \%$ in the third group. Among studies recruiting sewage workers and miners, three studies showed a higher and another, a lower prevalence of infection, with no adequate comparators. Similar results were found for travelers, with two studies showing a higher prevalence and two the opposite when compared to groups of the general population. Regarding transportation workers and teaching professionals, all studies identified presented a lower prevalence of $H$. pylori infection with no formal comparison. For workers at institutions for the intellectually disabled, $H$. pylori prevalence ranged between 14.1 and $47.1 \%$. The three studies identified showed a higher prevalence of $H$. pylori infection among these workers, although the difference was only statistically significant in one.

\section{Discussion}

Overall, most studies addressing the prevalence of $H$. pylori infection in specific occupational groups did not provide data from control groups not defined by their occupation. Nevertheless, gastrointestinal staff showed a statistically significant higher prevalence of $H$. pylori infection than their controls. Similar results were found for a high proportion of other health professionals and workers at institutions for the intellectually disabled. However, in the other occupational groups, differences in the prevalence of $H$. pylori when compared to the corresponding reference groups were less pronounced.

\section{Health professionals}

Among occupational groups with a high risk of infection, health professionals are a particularly susceptible group, as was observed during the outbreaks of severe acute respiratory syndrome (SARS) (Moore et al. 2005), Ebola (Kilmarx et al. 2014) and tuberculosis (Nasreen et al. 2016), particularly in professionals that have direct contact with body fluids or personal contact with patients, such as nurses, medical doctors and their respective assistants. Nevertheless, most of the hazardous exposures are preventable if professionals follow the international guidelines for infection control, regarding contact with infected patients, management of surgical and examination material and blood and body fluids, sanitation measures and good hygiene practices, such as hand washing with disinfectants and soap, use of gloves and personal protective equipment (Noone et al. 2006). These practices are of greater importance when there is some evidence of person-to-person transmission (Noone et al. 2006), even if the only proven transmission mode for $H$. pylori infection is iatrogenic contamination following endoscopy (Brown 2000). Therefore, personnel working directly with 
Table 2 Prevalence of $H$. pylori infection in health professionals and external comparators

Authors $\quad$ Prevalence of $H$. pylori infection (\%)

Year of publication

Occupational group External comparator

(Malaty et al. 1992)

Dentists $=17.0$

Dental hygienists $=18.0$

Dental assistants $=34.0$

Dental students $=25.0$

(Goh et al. 1996)

(Potts et al. 1997)

(Potasman and Yitzhak 1998)

(Gasbarrini et al. 2001)

(Sachdev et al. 2001)

(van der Voort et al. 2001)

(Angtuaco et al. 2002)

(Matsuda et al. 2002)

(Triantafillidis et al. 2002)

(Hoffmann et al. 2003)

(Melo et al. 2003)

(Birkenfeld et al. 2004)

(Mastromarino et al. 2005)

(Garza Yado Mde et al. 2006)

(Noone et al. 2006)

(Almadi et al. 2007)

(Campuzano-Maya et al. 2007)

(Velasco Elizalde et al. 2007)

(Monno et al. 2008)

(Eshraghian et al. 2009)

(Loster et al. 2009)

(Castro-Fernandez et al. 2012)

(Takashima et al. 2012)

Dentists $=42.3$
Endoscopy personnel $=32.9$

Endoscopists $=41.2$

Endoscopy nurse assistants $=27.1$

Non-endoscopy medical personnel $=12.0$

Gastroenterologists $=50.0$

Respiratory physicians $=10.0$

Medical students $=39.5$

Health-care workers $=40.0$

Conference delegates $=57.3$

ICU nurses with SDD unit $=18.0$

Other ICU nurses $=28.8$

Health-care workers $=22.9$

Gastrointestinal endoscopy personnel $=24.3$

Nurses

$1994=48.6$

$1999=61.0$

Medical staff

$1994=41.9$

$1999=51.6$

Paramedical staff

$1994=30.0$

$1999=46.7$

Medical students $=9.5$

Basic level medical students $=23.4$

Professional level medical students $=32.0$

Medical residents $=38.6$

Gastroenterology units staff members $=72.6$

Primary care clinic staff members $=71.4$

Gastrointestinal endoscopy personnel $=37.0$

General medical staff $=35.2$

Resident physicians $=24.6$

Gastroscopy nurses $=32.4$

Non-gastroscopy nurses $=33.1$

Medical students $=35.0$

Doctors $=77.2$

Endoscopy workers $=39.5$

Non-gastroenterology workers $=7.9$

Health-care workers $=77.9$

Health-care workers $=60.6$

Dentists $=70.0$

Medicine/nursing students $=32.7$

Medical students $=12.4$ $32.7^{\mathrm{a}}$ (Everhart et al. 2000)

35.9 (Goh and Parasakthi 2001)

27.7 (Moayyedi et al. 2000)

46.5 (Gdalevich et al. 2000)

67.9 (Bazzoli et al. 2001)

54.0 (Nisha et al. 2016)

35.4 (Wagtmans et al. 1997)

32.0 (Cardenas and Graham 2005)

75.0 (Sasazuki et al. 2006)

49.1 (Triantafillidis et al. 2003)

33.1 (Bode et al. 2001)

84.7 (Souto et al. 1998)

67.9 (Bazzoli et al. 2001)

75.4 (Ornelas et al. 2007)

66.0 (Woodward et al. 2000)

0.0 (Al-Refai et al. 2002)

75.4 (Bravo et al. 2002)

$-$

75.0 (Resuli et al. 1999)

69.0 (Nouraie et al. 2009)

84.2 (Laszewicz et al. 2014)

55.7 (Lopez-Saez et al. 2010)

24.4 (Fujimoto et al. 2007)

$I C U$ intensive care unit, $S D D$ selective decontamination of the digestive tract

${ }^{a}$ Age-standardized $H$. pylori prevalence 
Table 3 Prevalence of $H$. pylori infection in occupational groups and in study comparators, and $p$ value and/or risk of infection

\begin{tabular}{|c|c|c|c|}
\hline \multirow{2}{*}{$\begin{array}{l}\text { Authors } \\
\text { Year of publication }\end{array}$} & \multicolumn{2}{|l|}{ Prevalence of $H$. pylori infection (\%) } & \multirow{2}{*}{$\begin{array}{l}p \text { Value and/or risk } \\
\text { of infection (RR/OR, } \\
95 \% \mathrm{CI})^{\mathrm{a}}\end{array}$} \\
\hline & Occupational group & In study comparator & \\
\hline \multicolumn{4}{|l|}{ Administrative staff } \\
\hline Kim et al. (2013) & Office, administration, technical and pharmacy workers $=30.7$ & Nonhospital controls $=52.9$ & - \\
\hline \multicolumn{4}{|c|}{ Agricultural, forestry and fishery workers } \\
\hline Rocha et al. (1992) & $\begin{array}{l}\text { Abattoir workers }=65.6 \\
\text { Abattoir workers with no direct contact with the animals }=65.0\end{array}$ & Blood donors $=61.8$ & $p=0.56$ \\
\hline Ullah et al. (2010) & Fish handlers $=77.3$ & Non-fish handlers $=37.5$ & $p<0.001$ \\
\hline \multicolumn{4}{|l|}{ Armed forces } \\
\hline Pateraki et al. (1990) & Recruits $=67.0$ & Blood donors $=70.0$ & - \\
\hline \multicolumn{4}{|c|}{ Workers at institutions for intellectually disabled people } \\
\hline Bohmer et al. (1997) & $\begin{array}{l}\text { Employees at in institutes for the intellectually disabled }=27.2 \\
\text { Group } 1=31.6 \\
\text { Groups } 2 / 3=14.1\end{array}$ & $\begin{array}{l}\text { Control group }=25.0 \\
\text { (Loffeld et al. 1990) }\end{array}$ & - \\
\hline
\end{tabular}

$R R$ relative risk, $O R$ odds ratio, $95 \%$ CI 95\% confidence interval

aReference category is "in study comparator" and "occupational group" is the risk group, unless otherwise specified

endoscopic material and with infected patients represent a potential risk group (De Schryver et al. 2004).

The risk of $H$ pylori infection among gastroenterologists and their assistants was previously evaluated (Peters et al. 2011) and an increased risk, as observed from our results, was described. However, the statistical significance of the increased risk shown before depended on the type of controls used in each study, with only comparisons with nonmedical controls leading to statistically significant results. The main conclusion of Peters et al. was that further studies involving suitable control groups should be conducted for a valid assessment of occupational exposure risks. Our results support those of the previous review and add to that list of studies those recruiting dental staff as well as other health professionals. The latter have been widely used as controls for gastroenterology staff, contributing to the absence of statistically significant differences in the prevalence of $H$. pylori between the two groups.

To have an extensive overview of $H$. pylori infection in occupational groups, we have included in our systematic review reports recruiting occupational groups as controls. In that case, we selected an external comparator included in a systematic review on the prevalence of $H$. pylori worldwide (Peleteiro et al. 2014), from which the present systematic review was also derived. However, this option has compromised the formal comparison between occupational groups and the general population. Nevertheless, even when comparators were recruited in the same study, a statistical comparison was not always available, resulting in reporting bias. Furthermore, studies recruiting other occupational groups or unsuitable controls, such as symptomatic patients, as the reference group to be compared with the health professionals had to be excluded if no other adequate comparator could be found. This strategy, however, has minimized publication bias as these studies would have been excluded when performing a quantitative synthesis of the results.

\section{Other occupations}

Most studies focusing on subjects within the armed forces show a lower prevalence of infection than the general population of the same country. These results may be explained by the fact that most of these studies evaluated recruits at the beginning of their military training. Therefore, this occupational group is mainly composed of young males that are typically healthier than the general population (Carreira et al. 2012) and who have not yet been exposed to the expected risk factors in a military environment, such as poor sanitary and hygienic conditions during missions abroad. When that occurs, some studies show a higher prevalence of H. pylori infection when compared with the general population (Shinchi et al. 1997; Taylor et al. 1997).

Other occupational groups that were expected not to be at an increased risk of acquiring $H$. pylori infection were administrative staff, and transportation and factory workers. The lower prevalence found in our systematic review confirms this assumption. Conversely, the other occupational groups were expected to have an increased risk of $H$. pylori infection. Overall, our results support this hypothesis for sewage workers and miners, and for workers at institutions for the intellectually disabled, but not for those involved in agriculture, forestry and fishery, teaching professionals, and travelers. This may be because the latter is a more heterogeneous group, with missionaries moving from high- to lowincome countries, whereas migrant workers have an opposite pattern of migration (De Schryver et al. 2004). Regarding 
Table 4 Prevalence of $H$. pylori infection in occupational groups and external comparators

\begin{tabular}{lll}
\hline Authors & Prevalence of $H$. pylori infection $(\%)$ & External comparator \\
\cline { 2 - 3 } Year of publication & Occupational group & \\
\hline
\end{tabular}

Administrative staff

Husson et al. (1991)

Parsonnet et al. (1992)

Webb et al. (1994)

Friis et al. (1996)

Goh et al. (1996)

Kikuchi et al. (1998)

(Chiloiro et al. 2001)

Matsuda et al. (2002)

Triantafillidis et al. (2002)

Chimienti et al. (2003)

Mastromarino et al. (2005)

De Schryver et al. (2008)

Satoh et al. (2010)

Agricultural, forestry and fishery workers

Husson et al. (1991)

Laurila et al. (1999)

Babazono et al. (2004)

Bener et al. (2006)

Liu et al. (2007)

Hu et al. (2013)

Armed forces

Hammermeister et al. (1992)

Basso et al. (1994)

Smoak et al. (1994)

Hyams et al. (1995)

Shinchi et al. (1997)

Stroffolini et al. (1998)

Taylor et al. (1997)

Biselli et al. (1999)

Kyriazanos et al. (2001)

Kyriazanos et al. (2002)
Abattoir clerks and painters $=6.1$

Epidemiologists $=19.9$

Non-manual occupation $=21.5$

Laborers $=29.0$

Sales personnel from pharmaceutical companies $=10.7$

Public service workers $=30.5$

Administrative staff $=50.0$

College employees $=40.0$

Administrative and

technical staff

$1994=44.1$

$1999=55.1$

Faculty staff $=72.0$

Health-care personnel with no patient contact $=19.2$

Administrative workers $=29.2$

Local government employees $=45.4$

Poultry internal organ workers $=24.3$

Poultry carcass workers $=19.5$

Pig carcass workers $=14.8$

Polyvalent slaughterers $=14.8$

Reindeer herders $=65.1$

Agricultural workers $=52.7$

Farmers

$\mathrm{IgG}=77.6$

$\operatorname{IgA}=55.3$

Farmers and herders $=35.4$

Maritime workers $=44.9$

German submarine crews $=31.7$

German air force $=16.2$

French infantry regular officers $=13.7$

French infantry recruits $=18.5$

Soldiers and officers $=31.5$

Private, trooper, signalman, gunner and corporal $=30.0$

Sergeant, company, sergeant major $=53.8$

Lieutenant, captain, commandant $=14.3$

Recruits $=26.3$

Recruits $=24.0$

Shipboard personnel $=26.0$

Desert Storm troops $=22.0$

Self-defense officials $=79.3$

According to rank

Low $=82.5$

Middle $=75.2$

High $=75.0$

Air force students $=17.5$

Soldiers $=37.2$

Air force students $=17.2$

Navy recruits $=19.0$

Navy recruits $=27.2$
32.9 (Bergey et al. 2005)

$32.7^{\mathrm{a}}$ (Everhart et al. 2000)

13.4 (Vyse et al. 2002)

18.0 (Sorberg et al. 2003)

35.9 (Goh and Parasakthi 2001)

75.0 (Sasazuki et al. 2006)

45.0 (Palli et al. 1993)

75.0 (Sasazuki et al. 2006)

49.1 (Triantafillidis et al. 2003)

57.7 (Zagari et al. 2010)

67.9 (Bazzoli et al. 2001)

14.6 (De Hert et al. 1997)

75.0 (Sasazuki et al. 2006)

32.9 (Bergey et al. 2005)

59.0 (Salomaa-Rasanen et al. 2006)

75.0 (Sasazuki et al. 2006)

$-$

56.4 (Chen et al. 2007)

56.4 (Chen et al. 2007)

40.7 (Kuepper-Nybelen et al. 2005)

32.9 (Bergey et al. 2005)

43.0 (Buckley et al. 1998)

32. $7^{\mathrm{a}}$ (Everhart et al. 2000)

$32.7^{\mathrm{a}}$ (Everhart et al. 2000)

70.0 (Kikuchi et al. 2005)

45.0 (Palli et al. 1993)

$32.7^{\mathrm{a}}$ (Everhart et al. 2000)

45.0 (Palli et al. 1993)

49.1 (Triantafillidis et al. 2003)

49.1 (Triantafillidis et al. 2003) 
Table 4 (continued)

Authors

Year of publication

Prevalence of $H$. pylori infection (\%)

Fureszet al. (2004)

Furesz et al. (2004)

Occupational group

External comparator

Jackman et al. (2006)

First screening $=23.0$

Second screening $=33.0$

Monno et al. (2008)

Navy submarine crews $=10.4$

Conscripts $=53.8$

59.0 (Kalabay et al. 2002)

Factory workers

Webb et al. (1994)

Manual occupation $=39.9$

32.0 (Cardenas and Graham 2005)

Furuta et al. (1997)

Yang et al. (1999)

Ogihara et al. (2000)

Factory workers $=40.0$

Employees working in a manufacturing plant $=39.6$

Workers in textile companies $=48.3$

75.0 (Resuli et al. 1999)

Bener et al. (2006)

Skilled and unskilled professional workers

$\mathrm{IgG}=69.7$

$\operatorname{IgA}=46.7$

Pfefferle and Kramer (2008)

Employees $=42.8$

Van Hooste et al. (2010)

Laboratory personnel, operators and maintenance workers $=13.6$

van Mark et al. (2010)

All workers $=27.6$

Shift workers $=34.6$

Shift workers with night shifts $=34.7$

Shift workers without night shifts $=34.2$

Daytime workers $=16.0$

Daytime workers, never shift work $=13.4$

Daytime workers, former shift workers $=21.6$

Han et al. (2016)

Retirees $=49.6$

13.4 (Vyse et al. 2002)

70.0 (Kikuchi et al. 2005)

75.0 (Sasazuki et al. 2006)

70.0 (Kikuchi et al. 2005)

40.7 (Kuepper-Nybelen et al. 2005)

14.6 (De Hert et al. 1997)

40.7 (Kuepper-Nybelen et al. 2005)

Sewage workers $=28.5$

Sewage exposed workers $=33.6$

Sewage workers $=16.7$

Miners $=48.1$

Teachers $=30.8$

Teachers $=45.1$

Educators $=24.1$

46.8 (Cheng et al. 2009)

sewage workers and miners

Jeggli et al. (2004)

Van Hooste et al. (2010)

Siva et al. (2013)

Teaching professionals

Lin et al. v2000)

Lin et al. (2007)

Lynn et al. (2007)

Transportation workers

Vare et al. (2001)

Railway staff $=37.0$

Kim et al. (2005)

Subway workers $=77.4$

Saijo et al. (2007)

Transit company employees $=57.8$

18.0 (Sorberg et al. 2003)

57.1 (Ammann et al. 2000)

14.6 (De Hert et al. 1997)

13.4 (Vyse et al. 2002)

71.4 (Wang et al. 2008)

71.4 (Wang et al. 2008)

32.0 $0^{\mathrm{a}}$ (Cardenas and Graham 2005)

Monks $=77.2$

$59.0^{\mathrm{a}}$ (Salomaa-Rasanen et al. 2006)

80.8 (Shin et al. 2005)

75.0 (Sasazuki et al. 2006)

Katelaris et al. v1992)

Ahmad et al. (1997)

Migrant workers $=91.7$

61.5 (Wang et al. 2002)

Missionaries $=17.0$

(Xia et al. 2012)

Migrant workers $=41.0$

Workers at institutions for intellectually disabled people

Angtuaco et al. (2002)

HDC workers $=47.1$

De Schryver et al. (2008)

Workers in institutions for people with intellectual disability $=40.6$

$I g G$ immunoglobulin $\mathrm{G}, I g A$ immunoglobulin $\mathrm{A}, H D C$ human development center

${ }^{a}$ Age-standardized $H$. pylori prevalence 
Prevalence of $H$. pylori infection in occupational versus reference group

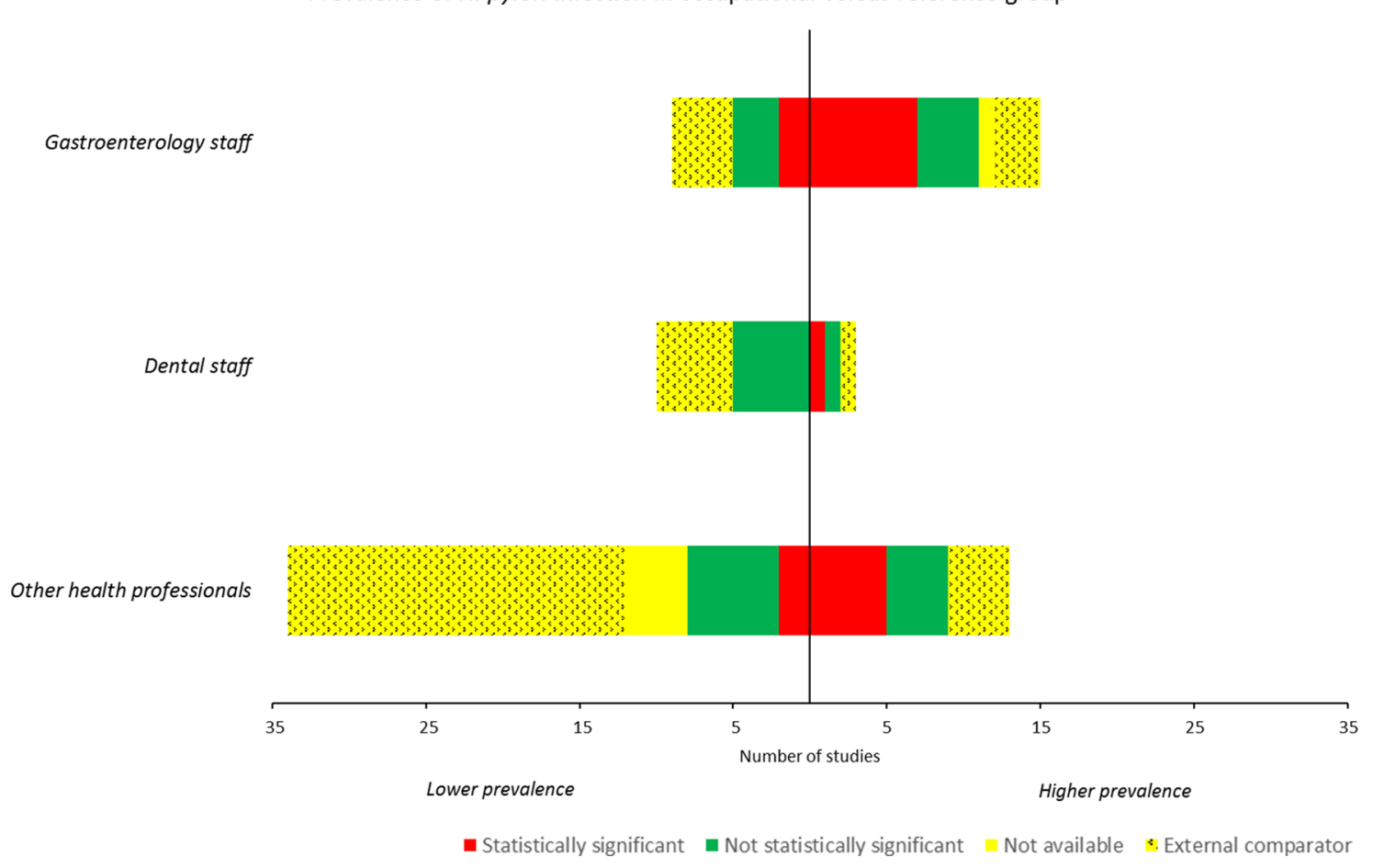

Fig. 1 Differences in the prevalence of Helicobacter pylori between health professionals and the reference group-clinical dental students (dental staff) from Banatvala et al. (1995) are not shown as they have the same prevalence as the control group. Gastroenterology unit staff members (gastroenterology staff) and primary care clinic staff mem-

teaching professionals, studies included in our systematic review were not conducted in day cares (Bastos et al. 2013), where the risk of acquiring $H$. pylori infection is higher due to the type of support needed by preschool children. Regarding agricultural, forestry, and fishery workers, in all the studies showing a lower prevalence when compared with the general population an external comparator was used. When the studies have recruited adequate control groups, the prevalence of $H$. pylori is higher in this occupational group, and in one study, statistical significance was reached.

\section{Strengths and limitations}

To the best of our knowledge, this is the first systematic review on the prevalence of $H$. pylori infection in occupational groups other than health professionals, with a comparison with the general population. Although only one electronic database was searched for our systematic review, a large amount of references was retrieved as well as great number of studies was included. Furthermore, as data analysis was essentially descriptive, no important bias is expected from this methodological option. In addition, our database search relied on a comprehensive expression contributing to increase the sensitivity of the search bers (other health professionals) from Birkenfeld et al. (2004) are not shown as no external comparator was available. Endoscopy workers (gastroenterology staff) and non-gastroenterology workers (other health professionals) from Velasco Elizalde et al. (2007) are not shown as no external comparator was available

and for a broad overview of the prevalence of $H$. pylori in different occupational groups. However, we were not able to retrieve nine full-text articles referring to occupational groups (Cupella et al. 1991; Glasbrenner et al. 1996; Kamat et al. 1999; Kopanski et al. 1997; Massarrat et al. 1995; Rudi et al. 1997; Salem et al. 1993; Sporea et al. 2003; Vaira and Holton 1998). Taking into account the information that could be accessed through the abstract of these articles, one would have been excluded because of no mention of a specific occupational group, while the remaining addressed the prevalence of $H$. pylori infection in health professionals $(n=4)$, recruits $(n=2)$ and factory workers $(n=1)$, as well as pastoral nomads $(n=1)$. However, only two of these studies recruited a control group (blood donors and healthy volunteers), and none of them reported a formal comparison between the prevalence in the occupational and reference groups in the abstract. Therefore, the results reported here would not significantly change if these studies had been included in our systematic review.

Heterogeneity between studies is one established limitation of systematic reviews, and in this case, the largest source of differences between studies was the comparison group. We tried to reduce the sources of heterogeneity by excluding studies that did not provide estimates of $H$. pylori 




Fig. 2 Differences in the prevalence of Helicobacter pylori between the occupational group and the reference group-farmers (agricultural, forestry, and fishery workers), and skilled and unskilled pro-

prevalence in specific occupational groups, because they recruited a mixture of different occupations or mixed occupational groups with other population types. In addition, comparisons made between the occupational and the reference group using prevalences obtained from papers other than the ones describing occupational groups may have influenced our results. Although this selection was based on a previous detailed assessment of each eligible study to be selected as possible reference (carried out independently of the specific objective of this systematic review), it should be noted that the studies are not entirely concordant regarding the period of data collection; therefore, comparisons should be made cautiously as the prevalence of infection has decreased over time, at an international level (Peleteiro et al. 2014). To minimize potential bias, we attempted to choose nationally representative or general population and age-specific estimates with a similar period of data collection. However, some studies presented blood donors as surrogate for the general population which may have introduced bias to the comparisons performed, since blood donors are generally considered healthier than the general population (Golding et al. 2013).

Even when adequate control groups and formal comparisons were presented in the studies, most of the results were not adjusted for covariates, resulting in lack of control fessional workers (Factory workers) from Bener et al. (2006) are not shown as no external comparator was available

for potential confounding, namely, by socioeconomic status (Eusebi et al. 2014). The evidence generated by the present systematic review is naturally limited by the quality and heterogeneity of the original reports regarding the methods used and the presentation of results. In addition, temporality between exposure and outcome, i.e., risk occupation and infection by $H$. pylori, cannot be assured, since most included studies had a cross-sectional design. Taken together, these factors preclude the establishment of a causal relation.

\section{Conclusion}

Although there is some debate about the occupational risk of acquiring $H$. pylori infection, we showed that health professionals are at higher risk of acquiring the infection, especially gastroenterology staff, favoring the iatrogenic route of transmission. However, other occupational groups, such as those working at institutions for the intellectually disabled, are also at higher risk of infection, supporting other routes of transmission, namely, person-to-person.

Further studies recruiting specific occupational groups should be conducted using adequate comparators and study designs to ascertain the main sources of $H$. pylori 
infection as well as to identify groups at higher risk of infection and ways to prevent it.

Nevertheless, our results suggest an evaluation of whether $H$. pylori infection can be included as an occupational disease, at least for some risk groups such as health professionals. This infection is not yet recognized by the several lists of occupational diseases that exist (European Commission 2003; International Labour Organization 2010), its inclusion would result in an early detection and treatment, as well as the prevention and control of its transmission at these workplaces.

Acknowledgements This study was funded by FEDER through the Operational Programme Competitiveness and Internationalization and national funding from the Foundation for Science and Technology-FCT (Portuguese Ministry of Science, Technology and Higher Education), under the Unidade de Investigação em EpidemiologiaInstituto de Saúde Pública da Universidade do Porto (EPIUnit) (POCI01-0145-FEDER-006862; Ref. UID/DTP/04750/2013). Individual PhD Grants attributed to AF (PD/BD/105823/2014), ARC (SFRH/ BD/102181/2014) and SM (SFRH/BD/102585/2014), and a Post-Doc Grant attributed to BP (SFRH/BPD/108751/2015) were funded by FCT and the "Programa Operacional Capital Humano" (POCH/FSE).

\section{Compliance with ethical standards}

Conflict of interest The authors declare that they have no conflict of interest.

\section{References}

Abbas Z, Jafri W, Khan AH, Shah MA (1998) Prevalence of Helicobacter pylori antibodies in endoscopy personnel and nonmedical volunteers of Karachi. J Pak Med Assoc 48:201-203

Ahmad MM et al (1997) Prevalence of Helicobacter pylori in asymptomatic population-a pilot serological study in Bangladesh. $\mathrm{J}$ Epidemiol 7:251-254

Allaker RP, Young KA, Hardie JM, Domizio P, Meadows NJ (2002) Prevalence of Helicobacter pylori at oral and gastrointestinal sites in children: evidence for possible oral-tooral transmission. J Med Microbiol 51:312-317. https://doi. org/10.1099/0022-1317-51-4-312

Almadi MA, Aljebreen AM, Tounesi FA, Abdo AA (2007) Helicobacter pylori prevalence among medical students in a high endemic area. Saudi Med J 28:896-898

Al-Refai AN, Fathalla SE, Nagamani R, Al-Momen S (2002) Incidence of Helicobacter pylori in dental plaque of saudi gastritis patients. J Family Community Med 9:27-36

Ammann P, Marschall S, Kraus M, Schmid L, Angehrn W, Krapf R, Rickli H (2000) Characteristics and prognosis of myocardial infarction in patients with normal coronary arteries. Chest 117:333-338

Angtuaco TL, Sharma VK, Corder FA, Raufman JP, Howden CW (2002) Seroprevalence of $H$. pylori infection and symptoms of upper gastrointestinal tract disease in two groups of health-care workers. Dig Dis Sci 47:292-297

Axon AT (1991) Disinfection of endoscopic equipment. Baillieres Clin Gastroenterol 5:61-77
Aziz RK, Khalifa MM, Sharaf RR (2015) Contaminated water as a source of Helicobacter pylori infection: a review. J Adv Res 6:539-547. https://doi.org/10.1016/j.jare.2013.07.007

Babazono A, Miyazaki M, Une H, Yamamoto E, Tsuda T, Mino Y, Hillman AL (2004) Does seropositivity for Helicobacter pylori antibodies increase outpatient costs for gastric and duodenal ulcer or inflammation? Pharmacoeconomics 22:975-983

Banatvala $\mathrm{N}$ et al (1995) Helicobacter pylori infection in dentists-a case-control study. Scand J Infect Dis 27:149-151

Basso L, Beattie S, Lawlor S, Clune J, O’Morain C (1994) A descriptive follow-up study on Helicobacter pylori infection before and after exposition to a war area. Eur J Epidemiol 10:109-111

Bastos J, Carreira H, La Vecchia C, Lunet N (2013) Childcare attendance and Helicobacter pylori infection: systematic review and meta-analysis. Eur J Cancer Prev 22:311-319. https://doi. org/10.1097/CEJ.0b013e32835b69aa

Bazzoli F et al (2001) The Loiano-Monghidoro population-based study of Helicobacter pylori infection: prevalence by 13C-urea breath test and associated factors. Aliment Pharmacol Ther 15:1001-1007

Becker SI, Smalligan RD, Frame JD, Kleanthous H, Tibbitts TJ, Monath TP, Hyams KC (1999) Risk of Helicobacter pylori infection among long-term residents in developing countries. Am J Trop Med Hyg 60:267-270

Bener A, Adeyemi EO, Almehdi AM, Ameen A, Beshwari M, Benedict S, Derballa MF (2006) Helicobacter pylori profile in asymptomatic farmers and non-farmers. Int J Environ Health Res 16:449454. https://doi.org/10.1080/09603120601093428

Bergenzaun P, Kristinsson KG, Thjodleifsson B, Sigvaldadottir E, Molstad S, Held M, Wadstrom T (1996) Seroprevalence of Helicobacter pylori in south Sweden and Iceland. Scand J Gastroenterol 31:1157-1161

Bergey B, Gallian P, Stuart M, Bolla JM, De Micco P, Megraud F (2005) Prevalence of Helicobacter pylori infection in Corsica. Gastroenterol Clin Biol 29:611-612

Birkenfeld S, Keter D, Dikman R, Shevah O, Shirin H, Niv Y (2004) Prevalence of Helicobacter pylori infection in health-care personnel of primary care and gastroenterology clinics. J Clin Gastroenterol 38:19-23

Biselli R, Fortini M, Matricardi PM, Stroffolini T, D’Amelio R (1999) Incidence of Helicobacter pylori infection in a cohort of Italian military students. Infection 27:187-191

Bode G, Hoffmeister A, Koenig W, Brenner H, Rothenbacher D (2001) Characteristics of differences in Helicobacter pylori serology and 13C-urea breath-testing in an asymptomatic sample of blood donors. Scand J Clin Lab Invest 61:603-608

Bohmer CJ, Klinkenberg-Knol EC, Kuipers EJ, Niezen-de Boer MC, Schreuder H, Schuckink-Kool F, Meuwissen SG (1997) The prevalence of Helicobacter pylori infection among inhabitants and healthy employees of institutes for the intellectually disabled. Am J Gastroenterol 92:1000-1004

Braden B, Duan LP, Caspary WF, Lembcke B (1997) Endoscopy is not a risk factor for Helicobacter pylori infection-but medical practice is. Gastrointest Endosc 46:305-310

Bravo LE, van Doom LJ, Realpe JL, Correa P (2002) Virulence-associated genotypes of Helicobacter pylori: do they explain the African enigma? Am J Gastroenterol 97:2839-2842. https://doi.org/ 10.1111/j.1572-0241.2002.07031.x

Brenner H, Weyermann M, Rothenbacher D (2006) Clustering of Helicobacter pylori infection in couples: differences between high- and low-prevalence population groups. Ann Epidemiol 16:516-520. https://doi.org/10.1016/j.annepidem.2005.09.009

Brown LM (2000) Helicobacter pylori: epidemiology and routes of transmission. Epidemiol Rev 22:283-297

Buckley MJ, O'Shea J, Grace A, English L, Keane C, Hourihan D, O'Morain CA (1998) A community-based study of the 
epidemiology of Helicobacter pylori infection and associated asymptomatic gastroduodenal pathology. Eur J Gastroenterol Hepatol 10:375-379

Campuzano-Maya G, Hoyos-Castano D, Calvo-Betancur VD, Suarez-Ramirez OA, Lizcano-Cardona D, Rojas-Arbelaez CA (2007) Prevalence of Helicobacter pylori infection in physicians in Medellin, Colombia. Acta Gastroenterol Latinoam 37:99-103

Cardenas VM, Graham DY (2005) Smoking and Helicobacter pylori infection in a sample of U.S. adults. Epidemiology 16:586-590

Carreira H, Pereira M, Azevedo A, Lunet N (2012) Effect of the type of population on estimates of mean body mass index and prevalence of overweight and obesity: a systematic review of studies of Portuguese adults. Ann Hum Biol 39:223-238. https://doi. org/10.3109/03014460.2012.681804

Castro-Fernandez M, Vargas-Romero J, Hoyas E, Lamas E, Millan R, Romero-Gomez M (2012) Relationship between H. pylori and hepatitis A virus infection. Rev Esp Enferm Dig 104:220-221

Cervantes DT, Fischbach LA, Goodman KJ, Phillips CV, Chen S, Broussard CS (2010) Exposure to Helicobacter pylori-positive siblings and persistence of Helicobacter pylori infection in early childhood. J Pediatr Gastroenterol Nutr 50:481-485. https://doi. org/10.1097/MPG.0b013e3181bab2ee

Chen J, Bu XL, Wang QY, Hu PJ, Chen MH (2007) Decreasing seroprevalence of Helicobacter pylori infection during 1993-2003 in Guangzhou, southern China. Helicobacter 12:164-169. https ://doi.org/10.1111/j.1523-5378.2007.00487.x

Cheng $\mathrm{H}$ et al (2009) Prevalence of Helicobacter pylori infection and identification of risk factors in rural and urban Beijing, China. Helicobacter 14:128-133. https://doi.org/10.111 1/j.1523-5378.2009.00668.x

Chiloiro M, Russo F, Riezzo G, Leoci C, Clemente C, Messa C, Di Leo A (2001) Effect of Helicobacter pylori infection on gastric emptying and gastrointestinal hormones in dyspeptic and healthy subjects. Dig Dis Sci 46:46-53

Chimienti G et al (2003) Helicobacter pylori is associated with modified lipid profile: impact on Lipoprotein(a). Clin Biochem 36:359-365

Chong J, Marshall BJ, Barkin JS, McCallum RW, Reiner DK, Hoffman SR, O'Phelan C (1994) Occupational exposure to Helicobacter pylori for the endoscopy professional: a sera epidemiological study. Am J Gastroenterol 89:1987-1992

Cover TL (1997) Commentary: Helicobacter pylori transmission, host factors, and bacterial factors. Gastroenterology 113:S29-30

Cupella F, Alessio I, Intropido L, Pozzi V, Einaudi A, Pozzi U (1991) Dyspepsia and Helicobacter pylori infection. A study of a population of workers. G Ital Med Lav 13:81-84

De Vecchi AF et al (1995) Epidemiology of Helicobacter pylori in dialysis patients. Perit Dial Int 15:178-179

De Hert M, Hautekeete M, De Wilde D, Peuskens J (1997) High prevalence of Helicobacter pylori in institutionalized schizophrenic patients. Schizophr Res 26:243-244

De Schryver AA, Van Hooste WL, Van Winckel MA, Van Sprundel MP (2004) Helicobacter pylori infection: a global occupational risk for healthcare workers? Int J Occup Environ Health 10:428432. https://doi.org/10.1179/oeh.2004.10.4.428

De Schryver A, Cornelis K, Van Winckel M, Moens G, Devlies G, Derthoo D, van Sprundel M (2008) The occupational risk of Helicobacter pylori infection among workers in institutions for people with intellectual disability. Occup Environ Med 65:587591. https://doi.org/10.1136/oem.2007.035022

Dore MP et al (1999) High prevalence of Helicobacter pylori infection in shepherds. Dig Dis Sci 44:1161-1164

Eshraghian A et al (2009) Helicobacter pylori infection as a risk factor for insulin resistance. Dig Dis Sci 54:1966-1970. https://doi. org/10.1007/s10620-008-0557-7
European Agency for Safety and Health at Work (2007) Risk assesment in health care. E-fact 18. Available at: http://osha.europa.eu

European Commission (2003) European list of occupational diseases Official Journal of the European Union. Available at: http://eurlex.europa.eu/LexUriServ/LexUriServ.do?uri=CELEX:32003 H0670:EN:NOT

Eusebi LH, Zagari RM, Bazzoli F (2014) Epidemiology of Helicobacter pylori infection. Helicobacter 19(Suppl 1):1-5. https://doi org/10.1111/hel.12165

Everhart JE, Kruszon-Moran D, Perez-Perez GI, Tralka TS, McQuillan G (2000) Seroprevalence and ethnic differences in Helicobacter pylori infection among adults in the United States. J Infect Dis 181:1359-1363. https://doi.org/10.1086/315384

Fantry GT, Zheng QX, James SP (1995) Conventional cleaning and disinfection techniques eliminate the risk of endoscopic transmission of Helicobacter pylori. Am J Gastroenterol 90:227-232

Ferro A et al (2014) Worldwide trends in gastric cancer mortality (1980-2011), with predictions to 2015, and incidence by subtype. Eur J Cancer 50:1330-1344. https://doi.org/10.1016/j. ejca.2014.01.029

Friis L, Engstrand L, Edling C (1996) Prevalence of Helicobacter pylori infection among sewage workers. Scand J Work Environ Health 22:364-368

Fujimoto Y, Furusyo N, Toyoda K, Takeoka H, Sawayama Y, Hayashi J (2007) Intrafamilial transmission of Helicobacter pylori among the population of endemic areas in Japan. Helicobacter 12:170176. https://doi.org/10.1111/j.1523-5378.2007.00488.x

Furesz J, Lakatos S, Nemeth K, Fritz P, Simon L, Kacserka K (2004) The prevalence and incidence of Helicobacter pylori infections among young recruits during service in the Hungarian Army. Helicobacter 9:77-80

Furuta T, Kamata T, Takashima M, Futami H, Arai H, Hanai H, Kaneko E (1997) Study of transmission routes of Helicobacter pylori in relation to seroprevalence of hepatitis A virus. J Clin Microbiol 35:1891-1893

Garza Yado Mde L et al (2006) Prevalence of seropositividad to antibodies IgG and IgM against Helicobacter pylori in the medical residents of the University Hospital of Puebla. Rev Alerg Mex 53:69-72

Garza-Gonzalez E, Perez-Perez GI, Maldonado-Garza HJ, BosquesPadilla FJ (2014) A review of Helicobacter pylori diagnosis, treatment, and methods to detect eradication. World J Gastroenterol 20:1438-1449. https://doi.org/10.3748/wjg.v20.i6.1438

Gasbarrini A et al (2001) Prevalence of and risk factors for Helicobacter pylori infection among healthcare workers at a teaching hospital in Rome: the Catholic University Epidemiological Study. Eur J Gastroenterol Hepatol 13:185-189

Gdalevich M, Cohen D, Ashkenazi I, Mimouni D, Shpilberg O, Kark JD (2000) Helicobacter pylori infection and subsequent peptic duodenal disease among young adults. Int J Epidemiol 29:592-595

Gisbert JP, Pajares JM (2004) Review article: 13C-urea breath test in the diagnosis of Helicobacter pylori infection -- a critical review. Aliment Pharmacol Ther 20:1001-1017. https://doi.org/10.111 1/j.1365-2036.2004.02203.x

Glasbrenner B, Malfertheiner P, Nilius M, Steinbruck C, Bruckel J, Wiesneth M, Adler G (1996) Prevalence of Helicobacter pylori infection and dyspepsia in young adults in Germany. Z Gastroenterol 34:478-482

Goh KL, Parasakthi N (2001) The racial cohort phenomenon: seroepidemiology of Helicobacter pylori infection in a multiracial South-East Asian country. Eur J Gastroenterol Hepatol 13:177-183

Goh KL, Parasakthi N, Ong KK (1996) Prevalence of Helicobacter pylori infection in endoscopy and non-endoscopy personnel: 
results of field survey with serology and 14C-urea breath test. Am J Gastroenterol 91:268-270

Golding J, Northstone K, Miller LL, Davey Smith G, Pembrey M (2013) Differences between blood donors and a population sample: implications for case-control studies. Int J Epidemiol 42:1145-1156. https://doi.org/10.1093/ije/dyt095

Goodman KJ et al (1996) Helicobacter pylori infection in the Colombian Andes: a population-based study of transmission pathways. Am J Epidemiol 144:290-299

Graham DY, Alpert LC, Smith JL, Yoshimura HH (1988) Iatrogenic Campylobacter pylori infection is a cause of epidemic achlorhydria. Am J Gastroenterol 83:974-980

Hammermeister I, Janus G, Schamarowski F, Rudolf M, Jacobs E, Kist M (1992) Elevated risk of Helicobacter pylori infection in submarine crews. Eur J Clin Microbiol Infect Dis 11:9-14

Han X et al (2016) Helicobacter pylori infection is associated with type 2 diabetes among a middle- and old-age Chinese population. Diabetes Metab Res Rev 32:95-101. https://doi.org/10.1002/ dmrr.2677

Hildebrand P, Meyer-Wyss BM, Mossi S, Beglinger C (2000) Risk among gastroenterologists of acquiring Helicobacter pylori infection: case-control study. Bmj 321:149

Hoffmann KM, Eherer AJ, Krejs GJ (2003) Are dyspeptic symptoms linked to Helicobacter pylori? A prospective cohort study among medical students. Wien Klin Wochenschr 115:175-178

Honda K, Ohkusa T, Takashimizu I, Watanabe M, Amagasa M (2001) High risk of Helicobacter pylori infection in young Japanese dentists. J Gastroenterol Hepatol 16:862-865

Hu D, Shao J, Wang L, Zheng H, Xu Y, Song G, Liu Q (2013) Prevalence and risk factors of Helicobacter pylori infection in Chinese maritime workers. Ann Hum Biol 40:472-476. https://doi. org/10.3109/03014460.2013.804121

Husson MO, Vincent P, Grabiaud MH, Furon D, Leclerc H (1991) Anti-Helicobacter pylori IgG levels in abattoir workers. Gastroenterol Clin Biol 15:723-726

Hyams KC, Taylor DN, Gray GC, Knowles JB, Hawkins R, Malone JD (1995) The risk of Helicobacter pylori infection among U.S. military personnel deployed outside the United States. Am J Trop Med Hyg 52:109-112

IARC Working Group on the Evaluation of Carcinogenic Risks to Humans (1994) Schistosomes, liver flukes and Helicobacter pylori. vol 61, 1994/01/01 edn. IARC, Lyon

International Labour Organization (2007) Resolution concerning updating the International Standard Classification of Occupations. ILO, Geneva

International Labour Organization (2010) ILO List of Occupational Diseases (revised 2010). Programme on Safety and Health at Work and the Environment (SafeWork). Available at: http://www. ilo.org/wcmsp5/groups/public/---ed_protect/---protrav/---safew ork/documents/publication/wcms_125137.pdf

Jackman RP, Schlichting C, Carr W, Dubois A (2006) Prevalence of Helicobacter pylori in United States Navy submarine crews. Epidemiol Infect 134:460-464. https://doi.org/10.1017/s0950 268805005169

Jeggli S, Steiner D, Joller H, Tschopp A, Steffen R, Hotz P (2004) Hepatitis E, Helicobacter pylori, and gastrointestinal symptoms in workers exposed to waste water. Occup Environ Med 61:622-627

Kalabay L et al (2002) Helicobacter pylori infection in connective tissue disorders is associated with high levels of antibodies to mycobacterial hsp65 but not to human hsp60. Helicobacter 7:250-256

Kamat AH, Mehta PR, Bhatia SJ, Koppikar GV (1999) Seroprevalence of IgG antibodies to Helicobacter pylori among gastrointestinal endoscopists, radiologists and paramedical personnel. J Assoc Physicians India 47:866-868
Katelaris PH, Tippett GH, Norbu P, Lowe DG, Brennan R, Farthing MJ (1992) Dyspepsia, Helicobacter pylori, and peptic ulcer in a randomly selected population in India. Gut 33:1462-1466

Kibria KM, Hossain ME, Sultana J, Sarker SA, Bardhan PK, Rahman M, Nahar S (2015) The prevalence of mixed Helicobacter pylori infections in symptomatic and asymptomatic subjects in Dhaka, Bangladesh. Helicobacter 20:397-404. https://doi.org/10.1111/ hel.12213

Kikuchi S, Kurosawa M, Sakiyama T (1998) Helicobacter pylori risk associated with sibship size and family history of gastric diseases in Japanese adults. Jpn J Cancer Res 89:1109-1112

Kikuchi S et al (2005) Serum pepsinogen values and Helicobacter pylori status among control subjects of a nested case-control study in the JACC study. J Epidemiol 15(Suppl 2):S126-133

Kilmarx PH et al (2014) Ebola virus disease in health care workers-Sierra Leone, 2014. MMWR Morb Mortal Wkly Rep 63:1168-1171

Kim N, Lim SH, Lee KH, Kim JM, Cho SI, Jung HC, Song IS (2005) Seroconversion of Helicobacter pylori in Korean male employees. Scand J Gastroenterol 40:1021-1027

Kim HY, Kim N, Kim SM, Seo JH, Park EH, Lee DH (2013) Seroprevalence of Helicobacter pylori Infection in Korean Health Personnel. Gut Liver 7:648-654. https://doi.org/10.5009/ gnl.2013.7.6.648

Kivi M, Tindberg Y (2006) Helicobacter pylori occurrence and transmission: a family affair? Scand J Infect Dis 38:407-417. https:// doi.org/10.1080/00365540600585131

Kopanski Z, Schlegel-Zawadzka M, Golec E, Witkowska B, Micherdzinski J, Cienciala A, Kustra Z (1997) The significance of selected epidemiologico-clinical factors in the prevalence of the Helicobacter pylori infection in young males. Eur J Med Res 2:358-360

Kuepper-Nybelen J, Thefeld W, Rothenbacher D, Brenner H (2005) Patterns of alcohol consumption and Helicobacter pylori infection: results of a population-based study from Germany among 6545 adults. Aliment Pharmacol Ther 21:57-64. https://doi.org /10.1111/j.1365-2036.2004.02276.x

Kyriazanos I, Ilias I, Lazaris G, Hountis P, Deros I, Dafnopoulou A, Datsakis K (2001) A cohort study on Helicobacter pylori serology before and after induction in the Hellenic Navy. Mil Med 166:411-415

Kyriazanos ID, Sfiniadakis I, Gizaris V, Hountis P, Hatziveis K, Dafnopoulou A, Datsakis K (2002) The incidence of Helicobacter pylori infection is not increased among obese young individuals in Greece. J Clin Gastroenterol 34:541-546

Lambert JR, Lin SK, Sievert W, Nicholson L, Schembri M, Guest C (1995) High prevalence of Helicobacter pylori antibodies in an institutionalized population: evidence for person-to-person transmission. Am J Gastroenterol 90:2167-2171

Langenberg W, Rauws EA, Oudbier JH, Tytgat GN (1990) Patient-topatient transmission of Campylobacter pylori infection by fiberoptic gastroduodenoscopy and biopsy. J Infect Dis 161:507-511

Laszewicz W, Iwanczak F, Iwanczak B (2014) Seroprevalence of Helicobacter pylori infection in Polish children and adults depending on socioeconomic status and living conditions. Adv Med Sci 59:147-150. https://doi.org/10.1016/j.advms.2014.01.003

Laurila A, Bloigu A, Nayha S, Hassi J, Leinonen M, Saikku P (1999) Association of Helicobacter pylori infection with elevated serum lipids. Atherosclerosis 142:207-210

Leung WK, Siu KL, Kwok CK, Chan SY, Sung R, Sung JJ (1999) Isolation of Helicobacter pylori from vomitus in children and its implication in gastro-oral transmission. Am J Gastroenterol 94:2881-2884. https://doi.org/10.1111/j.1572-0241.1999.01431 .x

Lin SK, Lambert JR, Schembri MA, Nicholson L, Korman MG (1994) Helicobacter pylori prevalence in endoscopy and medical staff. J Gastroenterol Hepatol 9:319-324 
Lin SK, Lambert JR, Schembri MA, Nicholson L, Johnson IH (1998) The prevalence of Helicobacter pylori in practising dental staff and dental students. Aust Dent J 43:35-39

Lin DB et al (2000) Association between seropositivity of antibodies against hepatitis a virus and Helicobacter pylori. Am J Trop Med Hyg 63:189-191

Lin DB, Lin JB, Chen CY, Chen SC, Chen WK (2007) Seroprevalence of Helicobacter pylori infection among schoolchildren and teachers in Taiwan. Helicobacter 12:258-264. https://doi.org/10.111 1/j.1523-5378.2007.00496.x

Liu WZ, Xiao SD, Jiang SJ, Li RR, Pang ZJ (1996) Seroprevalence of Helicobacter pylori infection in medical staff in Shanghai. Scand J Gastroenterol 31:749-752

Liu L, Liu Y, Tong W, Ye H, Zhang X, Cao W, Zhang Y (2007) Pathogen burden in essential hypertension. Circ J 71:1761-1764

Loffeld RJ, Stobberingh E, van Spreeuwel JP, Flendrig JA, Arends JW (1990) The prevalence of anti-Helicobacter (Campylobacter) pylori antibodies in patients and healthy blood donors. $\mathrm{J}$ Med Microbiol 32:105-109. https://doi.org/10.1099/00222 615-32-2-105

Lopez-Saez JB, Gomez-Biondi V, Santamaria-Rodriguez G, Dominguez-Villar M, Amaya-Vidal A, Lorenzo-Penuelas A, Senra-Varela A (2010) Concurrent overexpression of serum p53 mutation related with Helicobacter pylori infection. J Exp Clin Cancer Res 29:65. https://doi.org/10.1186/1756-9966-29-65

Loster BW et al (2009) Prevalence and characterization of Helicobacter pylori (H. pylori) infection and colonization in dentists. J Physiol Pharmacol 60(Suppl 8):13-18

Lunet N, Barros H (2003) Helicobacter pylori infection and gastric cancer: facing the enigmas. Int J Cancer 106:953-960. https:// doi.org/10.1002/ijc.11306

Lynn TV, Bruce MG, Landen M, Beller M, Bulkow L, Gold B, Parkinson A (2007) Helicobacter pylori infection among non-Native educators in Alaska. Int J Circumpolar Health 66:135-143

Makristathis A, Pasching E, Schutze K, Wimmer M, Rotter ML, Hirschl AM (1998) Detection of Helicobacter pylori in stool specimens by PCR and antigen enzyme immunoassay. J Clin Microbiol 36:2772-2774

Malaty HM, Evans DJ Jr, Abramovitch K, Evans DG, Graham DY (1992) Helicobacter pylori infection in dental workers: a seroepidemiology study. Am J Gastroenterol 87:1728-1731

Marshall B (2002) Helicobacter pylori: 20 years on. Clin Med (Lond) 2:147-152

Marshall BJ, Warren JR (1984) Unidentified curved bacilli in the stomach of patients with gastritis and peptic ulceration. Lancet 1:1311-1315

Martinez M, Kordisch F, Lesser S (2000) The prevalence of Helicobacter pylori: are emergency medicine residents at risk? J Emerg Med 19:213-215

Massarrat S, Saberi-Firoozi M, Soleimani A, Himmelmann GW, Hitzges M, Keshavarz H (1995) Peptic ulcer disease, irritable bowel syndrome and constipation in two populations in Iran. Eur J Gastroenterol Hepatol 7:427-433

Mastromarino P, Conti C, Donato K, Strappini PM, Cattaruzza MS, Orsi GB (2005) Does hospital work constitute a risk factor for Helicobacter pylori infection? J Hosp Infect 60:261-268. https ://doi.org/10.1016/j.jhin.2004.12.019

Matsuda R, Morizane T, Tsunematsu S, Kawana I, Tomiyama M (2002) Helicobacter pylori prevalence in dentists in Japan: a seroepidemiological study. J Gastroenterol 37:255-259

Megraud F, Broutet N (2000) Review article: have we found the source of Helicobacter pylori? Aliment Pharmacol Ther 14(Suppl 3):7-12

Megraud F, Lehours P (2007) Helicobacter pylori detection and antimicrobial susceptibility testing. Clin Microbiol Rev 20:280-322. https://doi.org/10.1128/cmr.00033-06
Melo ET, Lopes EP, Almeida JR, Albuquerque MF, Moura IM (2003) Seroprevalence of Helicobacter pylori antibodies in medical students and residents in Recife, Brazil. J Clin Gastroenterol 36:134-138

Miftahussurur M, Yamaoka Y (2016) Diagnostic methods of Helicobacter pylori infection for epidemiological studies: critical importance of indirect test validation. Biomed Res Int 2016:4819423. https://doi.org/10.1155/2016/4819423

Mitchell HM, Lee A, Carrick J (1989) Increased incidence of Campylobacter pylori infection in gastroenterologists: further evidence to support person-to-person transmission of $C$. pylori. Scand J Gastroenterol 24:396-400

Moayyedi P, Forman D, Braunholtz D, Feltbower R, Crocombe W, Liptrott M, Axon A (2000) The proportion of upper gastrointestinal symptoms in the community associated with Helicobacter pylori, lifestyle factors, and nonsteroidal anti-inflammatory drugs. Leeds HELP Study Group. Am J Gastroenterol 95:14481455. https://doi.org/10.1111/j.1572-0241.2000.2126_1.x

Mones J, Martin-de-Argila C, Samitier RS, Gisbert JP, Sainz S, Boixeda D (1999) Prevalence of Helicobacter pylori infection in medical professionals in Spain. Eur J Gastroenterol Hepatol $11: 239-242$

Monno R et al (2008) Helicobacter pylori seroprevalence in selected groups of Albanian volunteers. Infection 36:345-350. https:// doi.org/10.1007/s15010-008-6338-6

Moore D, Gamage B, Bryce E, Copes R, Yassi A (2005) Protecting health care workers from SARS and other respiratory pathogens: organizational and individual factors that affect adherence to infection control guidelines. Am J Infect Control 33:88-96. https://doi.org/10.1016/j.ajic.2004.11.003

Nasreen S, Shokoohi M, Malvankar-Mehta MS (2016) Prevalence of latent tuberculosis among health care workers in high burden countries: a systematic review and meta-analysis. PLoS One 11:e0164034. https://doi.org/10.1371/journal.pone.0164034

Nisha KJ, Nandakumar K, Shenoy KT, Janam P (2016) Periodontal disease and Helicobacter pylori infection: a community-based study using serology and rapid urease test. J Investig Clin Dent 7:37-45. https://doi.org/10.1111/jicd.12122

Nishikawa J, Kawai H, Takahashi A, Seki T, Yoshikawa N, Akita Y, Mitamura K (1998) Seroprevalence of immunoglobulin G antibodies against Helicobacter pylori among endoscopy personnel in Japan. Gastrointest Endosc 48:237-243

Noone PA, Waclawski ER, Watt AD (2006) Are endoscopy nurses at risk of infection with Helicobacter pylori from their work? Occup Med (Lond) 56:122-128. https://doi.org/10.1093/occme d/kqj013

Nouraie M et al (2009) Childhood hygienic practice and family education status determine the prevalence of Helicobacter pylori infection in Iran. Helicobacter 14:40-46. https://doi.org/10.1 111/j.1523-5378.2009.00657.x

Ogihara A, Kikuchi S, Hasegawa A, Kurosawa M, Miki K, Kaneko E, Mizukoshi H (2000) Relationship between Helicobacter pylori infection and smoking and drinking habits. J Gastroenterol Hepatol 15:271-276

Ornelas IJ, Galvan-Potrillo M, Lopez-Carrillo L (2007) Protective effect of yoghurt consumption on Helicobacter pylori seropositivity in a Mexican population. Public Health Nutr 10:12831287. https://doi.org/10.1017/s1368980007696372

Osato MS, Ayub K, Le HH, Reddy R, Graham DY (1998) Houseflies are an unlikely reservoir or vector for Helicobacter pylori. $\mathrm{J}$ Clin Microbiol 36:2786-2788

Palli D et al (1993) Helicobacter pylori antibodies in areas of Italy at varying gastric cancer risk. Cancer Epidemiol Biomarkers Prev 2:37-40 
Parkin DM (2006) The global health burden of infection-associated cancers in the year 2002. Int J Cancer 118:3030-3044. https:// doi.org/10.1002/ijc.21731

Parsonnet J, Blaser MJ, Perez-Perez GI, Hargrett-Bean N, Tauxe RV (1992) Symptoms and risk factors of Helicobacter pylori infection in a cohort of epidemiologists. Gastroenterology 102:41-46

Parsonnet J, Shmuely H, Haggerty T (1999) Fecal and oral shedding of Helicobacter pylori from healthy infected adults. JAMA 282:2240-2245

Pateraki E, Mentis A, Spiliadis C, Sophianos D, Stergiatou I, Skandalis N, Weir DM (1990) Seroepidemiology of Helicobacter pylori infection in Greece. FEMS Microbiol Immunol 2:129-136

Peleteiro B, La Vecchia C, Lunet N (2012) The role of Helicobacter pylori infection in the web of gastric cancer causation. Eur $\mathbf{J}$ Cancer Prev 21:118-125. https://doi.org/10.1097/CEJ.0b013 e32834a7f66

Peleteiro B, Bastos A, Ferro A, Lunet N (2014) Prevalence of Helicobacter pylori infection worldwide: a systematic review of studies with national coverage. Dig Dis Sci 59:1698-1709. https://doi. org/10.1007/s10620-014-3063-0

Peters C, Schablon A, Harling M, Wohlert C, Costa JT, Nienhaus A (2011) The occupational risk of Helicobacter pylori infection among gastroenterologists and their assistants. BMC Infect Dis 11:154. https://doi.org/10.1186/1471-2334-11-154

Pfefferle PI, Kramer A (2008) Helicobacter pylori-infection status and childhood living conditions are associated with signs of allergic diseases in an occupational population. Eur J Epidemiol 23:635640. https://doi.org/10.1007/s10654-008-9276-9

Plummer M, de Martel C, Vignat J, Ferlay J, Bray F, Franceschi S (2016) Global burden of cancers attributable to infections in 2012: a synthetic analysis. Lancet Glob Health 4:e609-616. https ://doi.org/10.1016/s2214-109X(16)30143-7

Potasman I, Yitzhak A (1998) Helicobacter pylori serostatus in backpackers following travel to tropical countries. Am J Trop Med Hyg 58:305-308

Potts LF, Lewis SJ, Mountford RA (1997) Prevalence of Helicobacter pylori in respiratory physicians performing bronchoscopy: a comparison with gastroenterologists using the carbon 13 urea breath test. Helicobacter 2:152-154

Pristautz H et al (1994) Prevalence of Helicobacter pylori antibodies in the serum of gastroenterologists in Austria. Endoscopy 26:690-696. https://doi.org/10.1055/s-2007-1009067

Pronai L, Schandl L, Tulassay Z (2000) Prevalence of Helicobacter pylori infection in Hungarian gastroenterologists and general practitioners. Eur J Gastroenterol Hepatol 12:473-474

Reiff A, Jacobs E, Kist M (1989) Seroepidemiological study of the immune response to Campylobacter pylori in potential risk groups. Eur J Clin Microbiol Infect Dis 8:592-596

Resuli B, Prifti S, Guma S, Stone M (1999) Prevalence of Helicobacter pylori infection in an Albanian population. Postgrad Med J 75:318

Ricci C, Holton J, Vaira D (2007) Diagnosis of Helicobacter pylori: invasive and non-invasive tests. Best Pract Res Clin Gastroenterol 21:299-313. https://doi.org/10.1016/j.bpg.2006.11.002

Robertson MS, Cade JF, Clancy RL (1999) Helicobacter pylori infection in intensive care: increased prevalence and a new nosocomial infection. Crit Care Med 27:1276-1280

Rocha GA, Queiroz DM, Mendes EN, Oliveira AM, Moura SB, Silva RJ (1992) Source of Helicobacter pylori infection: studies in abattoir workers and pigs. Am J Gastroenterol 87:1525

Roosendaal R, Kuipers EJ, van den Brule AJ, Pena AS, Meuwissen SG, Walboomers JM, de Graaff J (1993) Detection of Helicobacter pylori DNA by PCR in gastrointestinal equipment. Lancet 341:900
Rothenbacher D, Brenner H (2003) Burden of Helicobacter pylori and $H$. pylori-related diseases in developed countries: recent developments and future implications. Microbes Infect 5:693-703

Royo G, Ferez A, Esteban A, Martin C, Perez-Mateo M (1991) [Antibodies against Helicobacter pylori in gastroenterology personnel, patients and the healthy population]. Rev Esp Enferm Dig 80:233-236

Rudi J, Toppe H, Marx N, Zuna I, Theilmann L, Stremmel W, Raedsch R (1997) Risk of infection with Helicobacter pylori and hepatitis A virus in different groups of hospital workers. Am J Gastroenterol 92:258-262

Sachdev V, Ahuja V, Kumar D, Sharma MP (2001) Prevalence of Helicobacter pylori infection by $13 \mathrm{C}$-urea breath test in conference delegates. Indian J Gastroenterol 20:78

Saijo Y, Yoshioka E, Fukui T, Kawaharada M, Sata F, Sato H, Kishi $\mathrm{R}$ (2007) H. pylori seropositivity and cytokine gene polymorphisms. World J Gastroenterol 13:4445-4451

Salem OE, Thabet TM, El-Deeb SK, Youssri AH (1993) Study of the prevalence of specific human IgG against H. pylori among medical personnel. J Egypt Public Health Assoc 68:309-331

Salomaa-Rasanen A, Kosunen TU, Karjalainen J, Aromaa A, Knekt P, Sarna S, Rautelin H (2006) IgA antibodies in persisting Helicobacter pylori infection in Finnish adults. Clin Microbiol Infect 12:236-240. https://doi.org/10.111 1/j.1469-0691.2005.01357.x

Sasazuki S et al (2006) Effect of Helicobacter pylori infection combined with CagA and pepsinogen status on gastric cancer development among Japanese men and women: a nested case-control study. Cancer Epidemiol Biomarkers Prev 15:1341-1347. https ://doi.org/10.1158/1055-9965.epi-05-0901

Satoh H, Saijo Y, Yoshioka E, Tsutsui H (2010) Helicobacter pylori infection is a significant risk for modified lipid profile in Japanese male subjects. J Atheroscler Thromb 17:1041-1048

Shelley KH, Haddadin AS (1998) Is Helicobacter pylori infection an occupational hazard for anesthesiologists? Anesth Analg 87:973-974

Shimada T, Terano A, Ota S, Takikawa H, Sumino S (1996) Risk of iatrogenic transmission of Helicobacter pylori by gastroscopes. Lancet 347:1342-1343

Shin A, Shin HR, Kang D, Park SK, Kim CS, Yoo KY (2005) A nested case-control study of the association of Helicobacter pylori infection with gastric adenocarcinoma in Korea. Br J Cancer 92:1273-1275. https://doi.org/10.1038/sj.bjc.6602467

Shinchi K, Ishii H, Imanishi K, Kono S (1997) Relationship of cigarette smoking, alcohol use, and dietary habits with Helicobacter pylori infection in Japanese men. Scand J Gastroenterol 32:651-655

Siva R, Birring SS, Berry M, Rowbottom A, Pavord ID (2013) Peptic ulceration, Helicobacter pylori seropositivity and chronic obstructive pulmonary disease. Respirology 18:728-731. https ://doi.org/10.1111/resp.12075

Smoak BL, Kelley PW, Taylor DN (1994) Seroprevalence of Helicobacter pylori infections in a cohort of US Army recruits. Am J Epidemiol 139:513-519

Sorberg M, Nyren O, Granstrom M (2003) Unexpected decrease with age of Helicobacter pylori seroprevalence among Swedish blood donors. J Clin Microbiol 41:4038-4042

Souto FJ, Fontes CJ, Rocha GA, de Oliveira AM, Mendes EN, Queiroz DM (1998) Prevalence of Helicobacter pylori infection in a rural area of the state of Mato Grosso, Brazil. Mem Inst Oswaldo Cruz 93:171-174

Sporea I, Popescu A, van Blankenstein M, Sirli R, Focsea M, Danila M (2003) The prevalence of Helicobacter pylori infection in western Romania. Rom J Gastroenterol 12:15-18

Stroffolini T, Rosmini F, Ferrigno L, Fortini M, D'Amelio R, Matricardi PM (1998) Prevalence of Helicobacter pylori infection in a cohort of Italian military students. Epidemiol Infect 120:151-155 
Su YC, Wang WM, Chen LT, Chiang W, Chen CY, Lu SN, Jan CM (1996) High seroprevalence of IgG against Helicobacter pylori among endoscopists in Taiwan. Dig Dis Sci 41:1571-1576

Takashima T et al (2012) Endoscopic reflux esophagitis and Helicobacter pylori infection in young healthy Japanese volunteers. Digestion 86:55-58. https://doi.org/10.1159/000338849

Taylor DN, Sanchez JL, Smoak BL, DeFraites R (1997) Helicobacter pylori infection in Desert Storm troops. Clin Infect Dis 25:979-982

Testerman TL, Morris J (2014) Beyond the stomach: an updated view of Helicobacter pylori pathogenesis, diagnosis, and treatment. World J Gastroenterol 20:12781-12808. https://doi.org/10.3748/ wjg.v20.i36.12781

Triantafillidis JK et al (2002) Helicobacter pylori infection in hospital workers over a 5-year period: correlation with demographic and clinical parameters. J Gastroenterol 37:1005-1013. https://doi. org/10.1007/s005350200170

Triantafillidis JK et al. (2003) Relation between Helicobacter pylori infection, thyroid hormone levels and cardiovascular risk factors on blood donors. Hepatogastroenterology $50 \mathrm{Suppl}$ 2:cccxviii-cccxx

Ullah SS et al (2010) Seropositivity of Helicobacter pylori among the fish handlers. Mymensingh Med J 19:219-224

Upile T, East C, Paun S, Patel N, Battacharyya A (2002) Helicobacter pylori infection in surgical personnel. Clin Otolaryngol Allied Sci 27:310-313

Vaira D, Holton J (1998) Vector potential of houseflies (Musca domestica) for Helicobacter pylori. Helicobacter 3:65-66

Vaira D, Vakil N (2001) Blood, urine, stool, breath, money, and Helicobacter pylori. Gut 48:287-289

Van Hooste W, Charlier AM, Rotsaert P, Bulterys S, Moens G, van Sprundel M, De Schryver A (2010) Work-related Helicobacter pylori infection among sewage workers in municipal wastewater treatment plants in Belgium. Occup Environ Med 67:91-97. https ://doi.org/10.1136/oem.2008.040436

van Mark A, Spallek M, Groneberg DA, Kessel R, Weiler SW (2010) Correlates shift work with increased risk of gastrointestinal complaints or frequency of gastritis or peptic ulcer in H. pyloriinfected shift workers? Int Arch Occup Environ Health 83:423431. https://doi.org/10.1007/s00420-009-0495-5

van der Voort PH, van der Hulst RW, Zandstra DF, van der Ende A, Kesecioglu J, Geraedts AA, Tytgat GN (2001) Gut decontamination of critically ill patients reduces Helicobacter pylori acquisition by intensive care nurses. J Hosp Infect 47:41-45. https://doi. org/10.1053/jhin.2000.0861

Vare PO, Heikius B, Silvennoinen JA, Karttunen R, Niemela SE, Lehtola JK, Karttunen TJ (2001) Seroprevalence of Helicobacter pylori infection in inflammatory bowel disease: is Helicobacter pylori infection a protective factor? Scand J Gastroenterol 36:1295-1300

Velasco Elizalde C, Fernandez Ferrer MA, Rodriguez Muniz N (2007) Serologic diagnosis of Helicobacter pylori in endoscopy personnel. Serology in endoscopists. Rev Esp Enferm Dig 99:88-93

Versalovic J (2003) Helicobacter pylori. pathology and diagnostic strategies. Am J Clin Pathol 119:403-412

Vyse AJ et al (2002) The burden of Helicobacter pylori infection in England and Wales. Epidemiol Infect 128:411-417

Wagtmans MJ et al (1997) Low seroprevalence of Helicobacter pylori antibodies in historical sera of patients with Crohn's disease. Scand J Gastroenterol 32:712-718

Wang RT et al (2002) Helicobacter pylori infection and gastric cancer: evidence from a retrospective cohort study and nested case-control study in China. World J Gastroenterol 8:1103-1107

Wang X, Terry P, Yan H (2008) Stomach cancer in 67 Chinese counties: evidence of interaction between salt consumption and Helicobacter pylori infection. Asia Pac J Clin Nutr 17:644-650

Webb PM, Knight T, Greaves S, Wilson A, Newell DG, Elder J, Forman D (1994) Relation between infection with Helicobacter pylori and living conditions in childhood: evidence for person to person transmission in early life. Bmj 308:750-753

Weyermann M, Adler G, Brenner H, Rothenbacher D (2006) The mother as source of Helicobacter pylori infection. Epidemiology 17:332-334. https://doi.org/10.1097/01.ede.0000201257 .31155.a0

Wilhoite SL, Ferguson DA Jr, Soike DR, Kalbfleisch JH, Thomas E (1993) Increased prevalence of Helicobacter pylori antibodies among nurses. Arch Intern Med 153:708-712

Woodward M, Morrison C, McColl K (2000) An investigation into factors associated with Helicobacter pylori infection. J Clin Epidemiol 53:175-181

Xia P, Ma MF, Wang W (2012) Status of Helicobacter pylori infection among migrant workers in Shijiazhuang, China. Asian Pac J Cancer Prev 13:1167-1170

Yang X, Nishibayashi H, Takeshita T, Morimoto K (1999) Prevalence ofHelicobacter pylori infection in Japan: Relation to educational levels and hygienic conditions. Environ Health Prev Med 3:202206. https://doi.org/10.1007/bf02932259

Zagari RM, Law GR, Fuccio L, Pozzato P, Forman D, Bazzoli F (2010) Dyspeptic symptoms and endoscopic findings in the community: the Loiano-Monghidoro study. Am J Gastroenterol 105:565-571. https://doi.org/10.1038/ajg.2009.706 